\title{
Biotechnological basis for application of growth regulators for rooting of green cuttings of trees and shrubs in a greenhouse with a misting system
}

\author{
Roman A. Shchukin ${ }^{1, *}$, Oleg E. Bogdanov ${ }^{1}$, Ilya P. Zavoloka ${ }^{1}$, Gennady S. Ryazanov ${ }^{1}$, and \\ Nikolay M. Kruglov ${ }^{2}$ \\ ${ }^{1}$ Michurinsk State Agrarian University, Department of Landscape Architecture, Land Management \\ and Cadastres, 393760 Michurinsk, Russia \\ ${ }^{2}$ Michurinsk State Agrarian University, Department of Horticulture, 393760 Michurinsk, Russia
}

\begin{abstract}
This article presents data on the rooting of green cuttings of the studied species of ornamental trees and shrubs in a greenhouse with a misting system. We accounted the number of days from planting to the root formation and the number of rooted cuttings for each replication during our performance. We studied the influence of root formation stimulants on the rooting rate of various types of ornamental deciduous, flowering and coniferous plants. The effect of application of root formation stimulants is confirmed by the formation of a high-quality root system that is superior in length to those that were vegetated without "Kornevin". However, the use of root formation stimulants is not advisable on shrubby cinquefoil, common privet and common lilac "Mademoiselle Casimir Perier", because there is practically no increase in the rooting rate of cuttings in these plant species, compared to the control plants.
\end{abstract}

\section{Introduction}

In recent years, the problem of improving quality of life of the population has become urgent in our country in connection with economic and political reforms. Housing policy has changed dramatically, it has taken direction of meeting the needs of citizens not only in highquality and comfortable housing, but also in creating a comprehensive improvement of the entire adjacent territory, which includes not only installation of sports grounds and children playgrounds, small architectural forms, construction of paved roads and sidewalks, but also landscaping. Currently, there is a large amount of data confirming the relationship between the state of human health and the level of greening of the environment. Green spaces have a beneficial effect on the microclimatic conditions of an area. Plants and natural materials have an incredible ability to have a positive effect on the psychoemotional and physical state of people $[1,3,4]$.

${ }^{*}$ Corresponding author: roman-shchukin@list.ru 
At this stage, urbanization in the European part of Russia is distinguished by a wide scale of housing construction. Its characteristic feature is the territorial growth of settlements, namely the formation of new residential quarters and districts. Municipal courtyards have fallen into a dilapidated state in conditions of landscaping for many years. This does not comply with the norms of the Town-Planning and Housing Codes of the Russian Federation. Proceeding from this, the area of landscaped territories with the use of green plantations will increase massively. As a result, areas with the need for planting material of various types and forms of ornamental plants will dilate $[1,2,3,4,10]$.

\subsection{Research's objective and tasks}

Despite the potentiality of growing various types of ornamental trees and shrubs by the method of green cuttings in protected ground conditions using a misting system, this method of propagation has not been sufficiently studied. The objective of our research was to study the effect of the growth regulator "Kornevin" and its concentrations on the processes of root formation, growth and development of rooted cuttings belonging to various species groups of coniferous and ornamental tree and shrub cultures.

This research helped to solve the following tasks:

1. To establish the optimal timing for green cuttings.

2. To determine the rooting rate and timing of cuttings of various types of ornamental plants.

3. To study the issues of stimulating root formation in cuttings.

4. To determine quality of the root system and the roots length.

5. To establish the feasibility of using rooting stimulants.

\section{Materials and methods}

The research was carried out in 2015-2017 on the territory of the experimental field of the Fruit-and-Vegetable Growing Institute named after I.V. Michurin at the Michurinsk State Agrarian University in the educational farm "Roshcha" in Michurinsk, Tambov Oblast.

The objects of our research were plants that were growing on the ornamental and exhibition area of the park of the Michurinsk State Agrarian University: Juniperus squamata "Blue Carpet"; J. horizontalis "Andora Compacta"; Picea pungens "Glauca Misty Blue"; P. obovata "Apahti"; Thuja occidentalis "Golden Smaragt" and "Brabant"; Vulgaris Pentaphylloides fruticosa "Abbotswood" and "Goldfinger; Weigela praecox; W. hybrida; Hydrangea paniculata; H. arborescens; Cornus alba "Elegantissima" and "Sibirica"; Ligustrum vulgare; Deutzia scabra; Forsythia intermedia; Syringa vulgaris "Pavlinka", "Flora", "Mme Casimir Perier, "Primrose", "Jeanne d'Arc"; Physocarpus opulifolius "Diablo" and "Luteus"; Kerria japonica "Pleniflora"; Philadelphus coronarius "Gnom"; Spiraea japonica "Anthony Waterer" and "Pygmaea Alba"; Rosa hybrid tea "Bianca", "Friendship", "Black magic", "Limbo", "Cherry brandy" [5,6,7]. All studied plants were represented by 33 sample varieties.

The species, age and condition of the mother plant, the timing and conditions of cuttings have an impact on the rooting of cuttings. Conifers were cut in early spring (late April-early May), and ornamental deciduous and flowering plant species - in summer (June-early July), during the period of intensive shoot growth $[2,3,4,9]$.

Cuttings of ornamental deciduous and flowering shrubs were harvested early in the morning, cutting off with pruning shears from the apical lateral shoots of the current year. Specimens of 4-5 years of age were used as the mother plants. The younger the plant, the faster and better the rooting of the cuttings. On average, the size of the cuttings was at least 3 buds, the length varied from 4-7 cm (shrubby cinquefoil, Japanese spiraea) to $8-15 \mathrm{~cm}$ (panicled hydrangea, hybrid tea rose) $[3,10]$. To reduce the area of evaporation in large- 
leaved plants (common lilac, common ninebark), leaf blades were cut by $1 / 2$. In coniferous plants, cuttings were harvested manually by breaking off young shoots with a heel $7-10 \mathrm{~cm}$ long. It is important to ensure the preservation of moisture in the tissues in the process of harvesting cuttings, which also largely determines the success of rooting. All harvested cuttings were placed in water and pruned [6].

During the rooting of cuttings, the air temperature was maintained by airing and was about $25-32{ }^{\circ} \mathrm{C}$, the air humidity was within $95-98 \%$. These conditions were maintained in a polycarbonate greenhouse in the form of an arch with a size of 12 by $3 \mathrm{~m}$ and a height of 2 $\mathrm{m}$ with a misting system. Watering in the greenhouse was carried out every hour for 3 minutes each. In 25-30 days after setting the cuttings for rooting, the air humidity was reduced to $85 \%$. Then, during the period of mass root formation - it went down to $75-78 \%$. Due to this, plants quickly switch from heterotrophic nutrition to autotrophic $[6,7,8]$.

Peat + soil + river sand $(1: 1: 1)$ were used as a substrate. To increase the rooting rate, the cuttings were treated with a root formation stimulator. Half of the harvested plant cuttings were immersed by $1 / 3$ in a root solution (active ingredient is the indole-3-butyric acid (IBA)) and kept for 16 hours [10]. The products' concentration varied from $5 \mathrm{mg} / 1$ to $200 \mathrm{mg} / \mathrm{l}$, depending on the type of plant and the recommended application rate. The temperature of the aqueous solution when processing cuttings was $20-25^{\circ} \mathrm{C}$. After that, they were rinsed with clean water and planted in a greenhouse in previously prepared beds of $1.5-3.0 \mathrm{~cm}$ at a distance of 5-7 cm from each other. The second half of the cuttings was used as a control experiment; they were planted without treatment according to the same scheme. Cuttings were planted in triplicate, 20 cuttings each (60 cuttings per variant).

As a result of the research, the temperature and air humidity were determined. Weeds and dead cuttings were removed, the greenhouse was aired, and cuttings were treated with a fungicide during the research [9].

The number of days from planting to root formation, the rooting rate for each replication was counted and the length of the roots was measured during these studies.

\section{Results and discussion}

As a result of the research, we established, first of all, the influence of the genotype on the ability to reproduce by green cuttings. In the group of coniferous crops, significant differences were noted between junipers, thujas and spruces. The best rooting rate was noted in junipers, the lowest in spruce, and thuja took an intermediate position.

The greatest effect of "Kornevin" was revealed on the rooting of hard-to-root conifers, namely on the blue and Siberian spruce (Table 1). The yield of seedlings in flaky and horizontal junipers increased by 1.4-1.6 times, northern white-cedar - by 1.3-1.8 times, blue spruce and Siberian spruce - by 1.8-2.4 times, compared with the same variant, but without "Kornevin" that was taken for the control variant.

Application of "Kornevin" certainly influenced the quality of the root system. According to the results of the studies, the longest roots were $(8.3-8.6 \mathrm{~cm})$ in cuttings when using "Kornevin" (25 mg/l of IBA) (Flaky and horizontal junipers) (Fig. 1). In blue and Siberian spruce, the root length was $4.3-4.8 \mathrm{~cm}$, when using a $100 \mathrm{mg} / \mathrm{l}$ of IBA, depending on the variety, and in northern white-cedar - 7.6-7.9 cm using a $200 \mathrm{mg} / \mathrm{l}$ of IBA, when compared with the control variant without the root stimulator. 


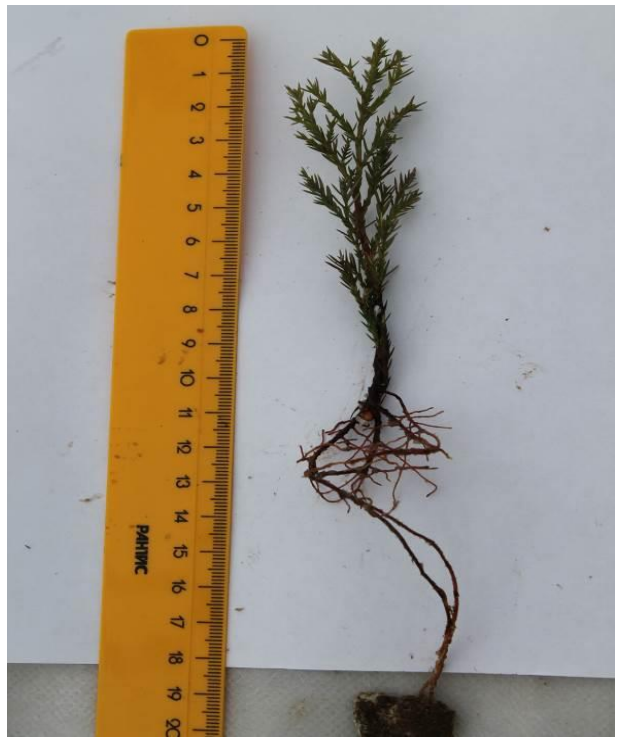

$\mathrm{a}$

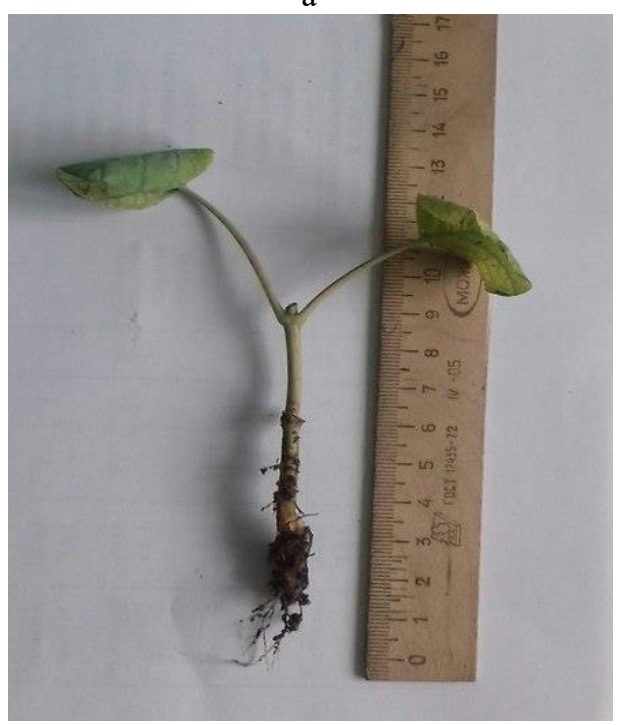

$\mathrm{c}$

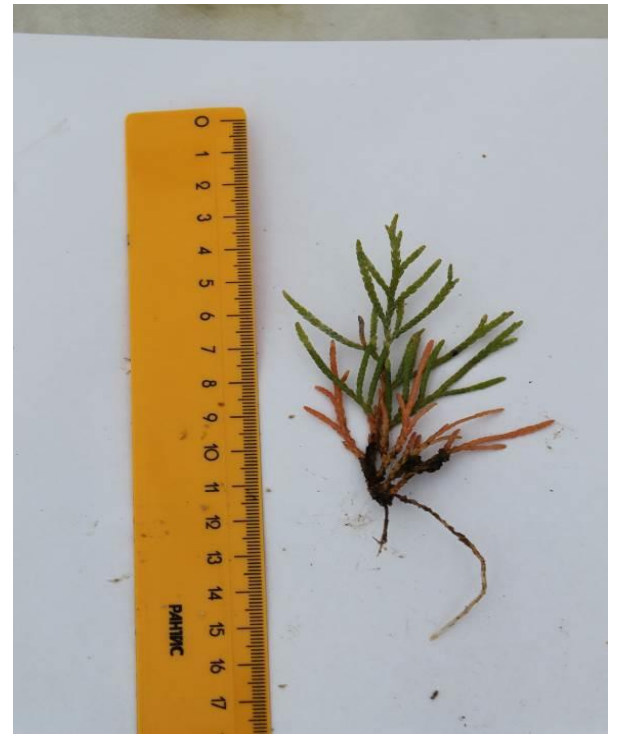

b

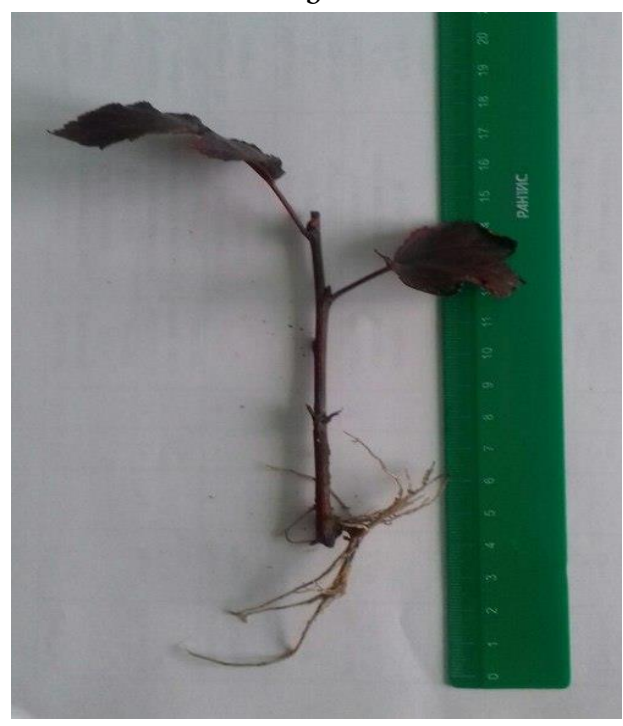

d

Fig. 1. Formation of viburnum roots on cuttings: a) flaky juniper; b) northern white-cedar; c) wild hydrangea; d) Diablo ninebark.

When studying the rooting rate of green cuttings of flowering shrubs and tree and shrub cultures, it should be noted that all the objects under the study are the easily rooted plants. The rooting rate of green cuttings varied from $62.8 \%$ without the rooting stimulant in the sweet mock-orange ("Gnom"), to $98.4 \%$ in shrubby cinquefoil ("Abbotswood"). Taking into account the indicator of the least significant difference, all objects of this group belong to the same statistical group.

Such species as cinquefoil, common privet and white dogwood, regardless of the variety, showed the least response to application of the root formation stimulator. The difference in rooting rate of cuttings, compared with the control, ranged from $0.5 \%$ to $6.6 \%$, and the average root length varied within $0.2-0.6 \mathrm{~cm}$. This indicates the inexpediency of using this 
stimulator of increasing root formation on the studied types. The rest of the ornamental deciduous and flowering shrubs gave a positive result for the "Kornevin" application, which revealed an increase in the rooting rate of cuttings and the formation of a high-quality root system, compared to the control variant.

Table 1. Efficiency of green cuttings of the following studied species of ornamental plants (average for 2015-2017).

\begin{tabular}{|c|c|c|c|c|c|c|c|}
\hline \multirow{3}{*}{ № } & \multirow{3}{*}{$\begin{array}{c}\begin{array}{c}\text { Research object } \\
\text { (variety) }\end{array} \\
\\
\text { Taxon in Latin }\end{array}$} & \multirow{3}{*}{$\begin{array}{c}\text { IBA } \\
\text { concentration, } \\
\mathrm{mg} / \mathbf{l}\end{array}$} & \multirow{2}{*}{\multicolumn{2}{|c|}{$\%$ of rooting }} & \multirow{3}{*}{$\begin{array}{c}\text { Duration of } \\
\text { rooting in } \\
\text { days }\end{array}$} & \multirow{2}{*}{\multicolumn{2}{|c|}{$\begin{array}{l}\text { Average root } \\
\text { length in } \mathrm{cm} .\end{array}$}} \\
\hline & & & & & & & \\
\hline & & & control & exp. & & control & exp. \\
\hline \multicolumn{8}{|c|}{ Coniferous cultures } \\
\hline 1 & $\begin{array}{l}\text { Juniperus squamata } \\
\text { (Blue Carpet) }\end{array}$ & \multirow[b]{2}{*}{25} & 65.4 & 72.1 & \multirow[b]{2}{*}{$40-60$} & 5.9 & 8.7 \\
\hline 2 & $\begin{array}{l}\text { Juniperus } \\
\text { horizontalis } \\
\text { (Andora Compacta) }\end{array}$ & & 53.2 & 57.3 & & 5.7 & 8.4 \\
\hline 3 & $\begin{array}{l}\text { Picea pungens } \\
\text { (Glauca Misty Blue) }\end{array}$ & \multirow{2}{*}{100} & 25.6 & 52.6 & \multirow{2}{*}{$50-70$} & 3.2 & 4.8 \\
\hline 4 & $\begin{array}{l}\text { Picea obovata } \\
\text { (Apahti) }\end{array}$ & & 19.8 & 46.4 & & 2.8 & 4.3 \\
\hline 5 & $\begin{array}{l}\text { Thuja occidentalis } \\
\text { (Golden Smaragt) }\end{array}$ & \multirow{2}{*}{200} & 39.2 & 55.3 & \multirow{2}{*}{$30-60$} & 5.1 & 7.9 \\
\hline 6 & $\begin{array}{l}\text { Thuja occidentalis } \\
\text { (Brabant) }\end{array}$ & & 36.8 & 57.8 & & 4.9 & 7.6 \\
\hline \multicolumn{2}{|c|}{$\mathrm{HCP}_{05}$} & & 10.1 & & & & \\
\hline \multicolumn{8}{|c|}{ Flowering shrubs and tree and shrub cultures } \\
\hline 7 & $\begin{array}{l}\text { Pentaphylloides } \\
\text { fruticosa } \\
\text { (Abbotswood) }\end{array}$ & \multirow{2}{*}{5} & 98.4 & 99.8 & \multirow{2}{*}{$18-23$} & 3.2 & 3.4 \\
\hline 8 & $\begin{array}{l}\text { Pentaphylloides } \\
\text { fruticosa } \\
\text { (Goldfinger) }\end{array}$ & & 98.1 & 98.6 & & 3.0 & 3.6 \\
\hline 9 & Weigela praecox & \multirow{2}{*}{10} & 78.5 & 98.5 & \multirow{2}{*}{$20-25$} & 4.7 & 7.4 \\
\hline 10 & Weigela hybrida & & 83.1 & 97.3 & & 4.0 & 6.8 \\
\hline 11 & $\begin{array}{l}\text { Hydrangea } \\
\text { paniculata }\end{array}$ & 5 & 74.2 & 87.2 & \multirow{2}{*}{$18-23$} & 4.2 & 7.1 \\
\hline 12 & $\begin{array}{l}\text { Hydrangea } \\
\text { arborescens }\end{array}$ & 50 & 68.7 & 89.4 & & 4.5 & 7.8 \\
\hline 13 & $\begin{array}{l}\text { Cornus alba } \\
\text { (Elegantissima) }\end{array}$ & \multirow{2}{*}{10} & 93.3 & 99.9 & \multirow{2}{*}{$15-23$} & 6.9 & 7.2 \\
\hline 14 & $\begin{array}{l}\text { Cornus alba } \\
\text { (ibirica) }\end{array}$ & & 96.8 & 99.8 & & 7.3 & 7.8 \\
\hline 15 & Ligustrum vulgare & 10 & 98.2 & 99.9 & $15-20$ & 6.5 & 6.8 \\
\hline 16 & Deutzia scabra & 10 & 87.2 & 92.1 & $17-25$ & 5.2 & 7.2 \\
\hline 17 & $\begin{array}{l}\text { Forsythia } \\
\text { intermedia }\end{array}$ & 25 & 64.3 & 85.9 & $25-35$ & 3.7 & 5.6 \\
\hline 18 & $\begin{array}{l}\text { Syringa vulgaris } \\
\text { (Pavlinka) }\end{array}$ & \multirow{2}{*}{50} & 87.2 & 92.4 & \multirow{2}{*}{$15-30$} & 3.2 & 5.4 \\
\hline 19 & $\begin{array}{l}\text { Syringa vulgaris } \\
\text { (Flora) }\end{array}$ & & 86.3 & 94.5 & & 4.1 & 6.3 \\
\hline
\end{tabular}




\begin{tabular}{|c|c|c|c|c|c|c|c|}
\hline 20 & $\begin{array}{ll}\text { Syringa } & \text { vulgaris } \\
\text { (Mme } & \text { Casimir } \\
\text { Perier) } & \end{array}$ & & 89.6 & 92.1 & & 5.8 & 6.1 \\
\hline 21 & $\begin{array}{ll}\text { Syringa } & \text { vulgaris } \\
\text { (Primrose) } & \end{array}$ & & 91.4 & 98.6 & & 3.9 & 5.9 \\
\hline 22 & $\begin{array}{l}\text { Syringa vulgaris } \\
\text { (Jeanne d'Arc) }\end{array}$ & & 87.3 & 98.7 & & 3.6 & 5.7 \\
\hline 23 & $\begin{array}{l}\text { Physocarpus } \\
\text { opulifolius } \\
\text { (Diablo) }\end{array}$ & \multirow[t]{2}{*}{50} & 82.8 & 96.8 & \multirow[t]{2}{*}{$20-25$} & 6.8 & 9.1 \\
\hline 24 & $\begin{array}{l}\text { Physocarpus } \\
\text { opulifolius (Luteus) }\end{array}$ & & 83.4 & 89.7 & & 5.3 & 8.7 \\
\hline 25 & $\begin{array}{l}\text { Kerria japonica } \\
\text { (Pleniflora) }\end{array}$ & 5 & 81.6 & 92.4 & $20-35$ & 3.7 & 5.6 \\
\hline 26 & $\begin{array}{l}\text { Philadelphus } \\
\text { coronarius (Gnom) }\end{array}$ & 25 & 62.8 & 74.3 & $25-35$ & 4.0 & 6.8 \\
\hline 27 & $\begin{array}{l}\text { Spiraea japonica } \\
\text { (Anthony Waterer) }\end{array}$ & \multirow[b]{2}{*}{50} & 81.3 & 91.7 & \multirow{2}{*}{$15-25$} & 3.6 & 5.8 \\
\hline 28 & $\begin{array}{l}\text { Spiraea japonica } \\
\text { (Pygmaea Alba) }\end{array}$ & & 76.8 & 88.2 & & 3.2 & 4.7 \\
\hline 29 & $\begin{array}{l}\text { Rosa hybrid tea } \\
\text { (Bianca) }\end{array}$ & \multirow{5}{*}{80} & 89.7 & 97.3 & \multirow{5}{*}{$12-28$} & 8.0 & 10.5 \\
\hline 30 & $\begin{array}{l}\text { Rosa hybrid tea } \\
\text { (Friendship) }\end{array}$ & & 91.4 & 98.2 & & 8.5 & 11.8 \\
\hline 31 & $\begin{array}{lr}\text { Rosa } & \text { hybrid } \\
\text { (Black } & \text { Magic) }\end{array}$ & & 89.6 & 93.8 & & 11.0 & 11.2 \\
\hline 32 & $\begin{array}{l}\text { Rosa hybrid tea } \\
\text { (Limbo) }\end{array}$ & & 83.1 & 94.1 & & 8.3 & 11.9 \\
\hline 33 & $\begin{array}{l}\text { Rosa hybrid tea } \\
\text { (Cherry Brandy) }\end{array}$ & & 86.3 & 92.6 & & 7.7 & 10.7 \\
\hline \multicolumn{2}{|c|}{$\mathrm{HCP}_{05}$} & & 38.1 & & & & \\
\hline
\end{tabular}

When studying the literature, we noted a different ability to root of different varieties of roses [3,7]. When rooting green cuttings of hybrid tea roses, "Kornevin" made it possible to increase the rooting rate by $6.7-9.4 \%$ and amounted to $92.6-98.2 \%$, depending on the variety. Thus, the rooting rate in varieties Bianca and Friendship was more than $95 \%$, when treated with a growth regulator; in varieties Black Magic, Limbo and Cherie Brandy $-90-95 \%$.

\section{Conclusion}

Research, conducted in the greenhouse with a misting system, allowed us to formulate the following conclusions:

1) we observed the efficiency of reproduction by green cuttings of Japanese spiraea (Anthony Waterer, Pygmaea Alba), when using growth substances;

2) "Kornevin" use promotes better root formation and adaptability to unfavourable growth conditions. We noted the best development of plants and the efficiency of the passage of physiological processes in this case;

3) we obtained the best results using the "Kornevin" product, based on indole-3-butyric acid, during the period of optimal rooting time with the majority of the studied plants;

4) we observed a high survival rate of cuttings of hybrid tea roses varieties, when the required concentration of stimulants for root formation was selected;

5) "Kornevin" application for green cuttings of ornamental species contributes to better rooting and a reduction in the time of root formation. When using the selected growth 
regulator, the conditions of use and types of ornamental plants should be adhered to. This gives the most effective use of "Kornevin", when grafting with green cuttings.

All tree and shrub species can be rooted with green cuttings. Root formation is observed on days 13-37 in deciduous trees and on days 35-75 in conifers. The root formation stimulant application did not show the expected effect on the rooting rate of cuttings and root formation in shrubby cinquefoil, common privet and white dogwood.

It is necessary to continue studying features of reproduction of the studied species in order to identify conditions for increasing the rooting rate of cuttings (selection of the root stimulator concentrations, rooting modes, etc.).

\section{References}

1. N. K. Vekhov, M. P. Ilyin, Vegetativnoe takih razmnozhenie drevesnyh gortenzii rastenij uslovij letnimi cherenkami [Vegetative propagation of woody plants by summer cuttings temperature] (Publishing house of VIR, Leningrad, 1934)

2. T. E. Galdina, Modern Science Success 11, 16 (2016)

3. Yu. V. Guryanova, V. V. Ryazanova, The Bulletin of Michurinsk State Agrarian University 6, 22 (2013)

4. N. N. Neshchadim, Mir teplic 5 (1998)

5. A. S. Khaladjyan, N. N. Neshchadim, T. D. Epishina, Scientific Journal of KubSAU 4 (2005)

6. N. N. Chesnokov, The Bulletin of Michurinsk State Agrarian University 6, 27 (2013)

7. R. A. Shchukin, I. P. Zavoloka, G. S. Ryazanov, V. V. Ryazanova, The Bulletin of Michurinsk State Agrarian University 4, 30 (2016)

8. O. V. Yudina, V. V. Ryazanova, R. A. Shchukin, G. S. Ryazanov, Nauchnye trudy CHeboksarskogo filiala GBS RAN 9, 205 (2017)

9. A. Pacholczak, W. Szydło, Ann. Warsaw Univ. of Life Sc. - SGGW, Horticult. and Landsc. Architect. 29, 53 (2008)

10. J. Kroin. Combined Proceedings International Plant Propagators' Society 42, 489 (1992) 